\title{
QUANDO VOCÊ É CUIDADO POR SEU COLEGA DE TRABALHO'
}

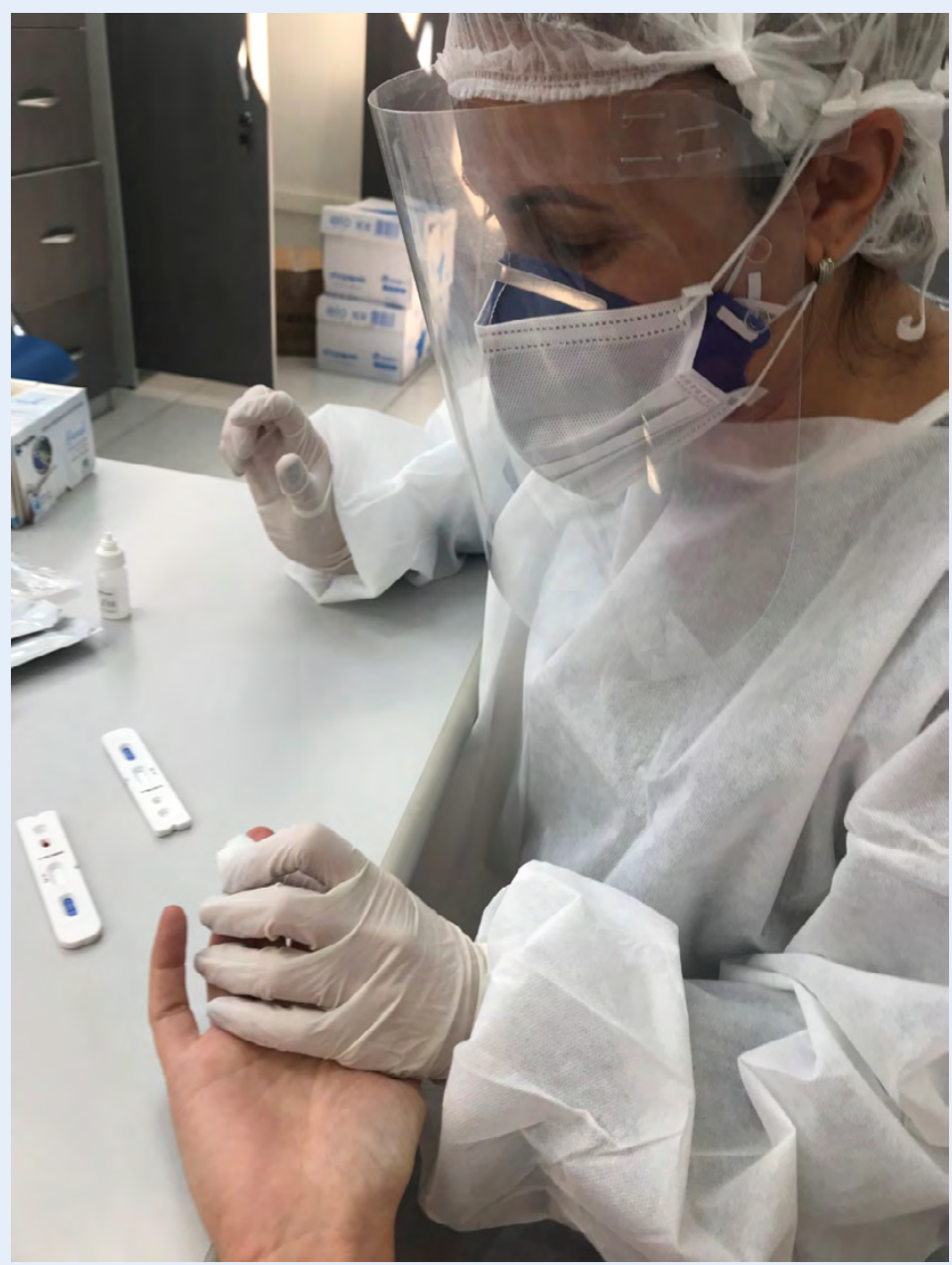

Créditos: Fernanda Vicenzi Pavan.

10 Quando o profissional de saúde se torna paciente, mesmo que por breve momento, e necessita do outro, gera certa insegurança. Porém, quando o colega de trabalho volta o seu olhar com afeto e legitima o sofrimento, aquele encontro torna-se potência e dissipa qualquer incerteza. 